\title{
Isatin inhibits the proliferation and invasion of SH-SY5Y neuroblastoma cells
}

\author{
PINGPING XU ${ }^{1}$, LIN HOU $^{1}$, CHUANXIA JU ${ }^{2}$, ZHENG ZHANG $^{1}$, WENYAN SUN ${ }^{1}$, \\ LI ZHANG $^{2}$, JINLIAN SONG ${ }^{3}$, YUQIANG LV ${ }^{1}$, LU LIU $^{1}$, ZHIXIANG CHEN $^{1}$ and YANHUI WANG ${ }^{1}$ \\ Departments of ${ }^{1}$ Biochemistry and ${ }^{2}$ Pharmacology, Medical College, Qingdao University, Qingdao, Shandong 266021; \\ ${ }^{3}$ Department of Laboratory, Women and Children's Hospital of Qingdao, Qingdao, Shandong 266011, P.R. China
}

Received January 28, 2015; Accepted November 17, 2015

DOI: $10.3892 / \mathrm{mmr} .2016 .4850$

\begin{abstract}
Isatin has been shown to initiate apoptotic processes in SH-SY5Y neuroblastoma cells. The aim of the present study was to investigate whether isatin is also able to alter the proliferation and migratory ability of SH-SY5Y cells. The results demonstrated that the proportion of SH-SY5Y cells in $\mathrm{G}_{1}$ phase was significantly increased following treatment with isatin for $48 \mathrm{~h}$ with simultaneous downregulation of cyclin D1 expression. In addition, isatin significantly inhibited cell migration and invasion, along with decreases in matrix metalloproteinase (MMP)2 and MMP9 expression. In addition, isatin reduced the levels of phosphorylated signal transducer and activator of transcription 3 (p-STAT3) in a concentration-dependent manner. These results demonstrated that isatin induces $\mathrm{G}_{1}$-phase arrest in SH-SY5Y cells, possibly by decreasing cyclin D1 expression as well as inhibiting their migration and invasiveness, probably by reducing MMP2 and MMP9. These effects may be exerted by isatin via a downregulating the levels of pSTAT3.
\end{abstract}

\section{Introduction}

Neuroblastoma, which are derived from the sympathetic nervous system, represent the forth most common type of extracranial malignant solid tumor in children (1). A variety of treatment approaches, including surgery, immunotherapy, apoptosis-inducing therapy, myeloablative chemotherapy and radionuclide therapy, are used in the clinic for inhibiting the rapid growth of neuroblastoma $(2,3)$. In the spite of the development of numerous anti-cancer drugs and therapies, the five-year survival rate remains $<75 \%$ owing to the high

Correspondence to: Professor Lin Hou, Department of Biochemistry, Medical College, Qingdao University, 38 Dengzhou Road, Qingdao, Shandong 266021, P.R. China

E-mail: qyhoulin@126.com

Key words: isatin, human neuroblastoma cell, proliferation, invasion, matrix metalloproteinase, cyclin D1, signal transducer and activator of transcription 3 proliferation and migratory ability of neuroblastoma $(4,5)$. Innovative therapeutic approaches using migratory inhibitors are expected to improve patient survival due to enhanced efficacy as well as reduced drug-associated toxicity.

$1 \mathrm{H}$-indole-2,3-dione (isatin) is a promising heterocyclic drug with numerous beneficial biological activities, including anti-bacterial, anti-fungal and anti-tumor properties (6). Derivatives of isatin have been demonstrated to exert inhibitory effects on tyrosine kinases and cyclin-dependent kinases (CDKs) as well as anti-angiogenic effects in tumor cells (7-11). Previous studies by our group suggested that isatin has marked pro-apoptotic effects on the SH-SY5Y neuroblastoma cell line in vitro and in vivo $(12,13)$. The present study investigated the anti-proliferative and anti-invasive effects of isatin on SH-SY5Y cells as well as the underlying molecular mechanisms.

\section{Materials and methods}

Cells and cell culture. The SH-SY5Y human neuroblastoma cell line was purchased from Peking Union Medical College (Beijing, China). Cells were cultured in Dulbecco's modified Eagle's medium (DMEM; Hyclone; Thermo Fisher Scientific, Inc., Waltham, MA, USA) supplemented with $10 \%$ fetal bovine serum (FBS; Gibco; Thermo Fisher Scientific, Inc.), $100 \mu \mathrm{g} / \mathrm{ml}$ streptomycin and $100 \mathrm{U} / \mathrm{ml}$ penicillin (both Solarbio Science \& Technology Co., Ltd., Beijing, China). The cells were cultured at $37^{\circ} \mathrm{C}$ in an humidified atmosphere of $95 \%$ air and $5 \% \mathrm{CO}_{2}$. Upon $70 \%$ confluency, isatin [in a $5 \mathrm{mM}$ stock solution in $0.1 \%$ dimethly sulfoxide (DMSO); Sigma-Aldrich, St. Louis, MO, USA] was added with final concentrations of 100 , 200 or $400 \mu \mathrm{M}$. Following incubation for $48 \mathrm{~h}$, the cells were harvested and subjected to analysis.

Flow-cytometric analysis. The treated cells were harvested by centrifugation and washed three times with phosphate-buffered saline. The cells were fixed with ice-cold $75 \%$ ethanol for $18 \mathrm{~h}$, stained with propidium iodide (Sigma-Aldrich) and then analyzed by flow cytometry (FACSCanto; BD Biosciences, Franklin Lakes, NJ, USA) to detect the cell cycle. A minimum of 10,000 events were analyzed in each experiment, and the results were analyzed using ModFit LT software, version 3.2 (Verity Software House, Inc., Topsham, ME, USA). 
Table I. Cell cycle distribution of SH-SY5Y cells treated with isatin for $48 \mathrm{~h}$ as determined by flow cytometry.

\begin{tabular}{llcr}
\hline & \multicolumn{3}{c}{ Cell population (\%) } \\
\cline { 2 - 4 } Group & $\mathrm{G}_{1}$ phase & S phase & $\mathrm{G}_{2} / \mathrm{M}$ phase \\
\hline Control & $54.18 \pm 0.47$ & $36.16 \pm 0.64$ & $9.66 \pm 1.12$ \\
$100 \mu \mathrm{M}$ isatin & $66.23 \pm 0.51^{\mathrm{a}}$ & $28.76 \pm 0.91^{\mathrm{a}}$ & $5.01 \pm 1.04$ \\
$200 \mu \mathrm{M}$ isatin & $67.40 \pm 0.17^{\mathrm{a}}$ & $28.98 \pm 0.68^{\mathrm{a}}$ & $3.62 \pm 0.51$ \\
$400 \mu \mathrm{M}$ isatin & $73.39 \pm 2.12^{\mathrm{a}, \mathrm{b}, \mathrm{c}}$ & $17.68 \pm 0.78^{\mathrm{a}, \mathrm{b}, \mathrm{c}}$ & $8.92 \pm 1.71$ \\
\hline
\end{tabular}

Values are expressed as the mean \pm standard deviation. ${ }^{a} \mathrm{P}<0.01$ compared with control; ${ }^{\text {b }}<0.01$ compared with $100 \mu \mathrm{M}$ isatin; ${ }^{\mathrm{c}} \mathrm{P}<0.01$ compared with $200 \mu \mathrm{M}$ isatin.

Invasion assay. The invasive potential of SH-SY5Y cells was examined using Transwell inserts (Corning Inc., Corning, NY, USA). The membranes were coated with Matrigel (BD Biosciences) for $30 \mathrm{~min}$. SH-SY5Y cells were trypsinized (Thermo Fisher Scientific, Inc.), re-suspended in serum-free medium and counted following serum starvation for $12 \mathrm{~h}$. The bottom wells of the Transwell inserts were filled with DMEM containing $10 \%$ FBS. Cells $\left(2 \times 10^{5}\right.$ in $200 \mu 1$ serum-free medium) were added to the upper compartment of each Transwell insert and incubated for $24 \mathrm{~h}$ in the absence or presence of isatin (100 or $200 \mu \mathrm{M})$. Cells that failed to migrate through the filter following incubation were removed using a sterile cotton swab, while invaded cells on the lower side of the filter were fixed with methanol (Sinopharm Chemical Reagent Co., Ltd., Shanghai, China) and stained with $0.1 \%$ crystal violet (Solarbio Science $\&$ Technology Co., Ltd.). The number of invaded cells in five random fields of the Transwell membrane was counted under a microscope (CKX41; Olympus Corporation, Tokyo, Japan).

Cell survival assay. An MTT assay was conducted in order to assess the survival of SH-SY5Y cells. Cells $\left(10^{3}\right.$ cells/well) were seeded into 96-well plates and isatin was added to a final concentration of $100 \mu \mathrm{M}-400 \mu \mathrm{M} 24 \mathrm{~h}$ later. Following incubation for $48 \mathrm{~h}$, the cells were incubated with MTT $(1 \mathrm{mg} / \mathrm{ml}$; Sigma-Aldrich) for $3 \mathrm{~h}$ at $37^{\circ} \mathrm{C}$, after which formazan crystals were dissolved in $100 \mu \mathrm{l}$ DMSO. The absorbance was measured at $490 \mathrm{~nm}$ using a microplate reader (Synergy H1; BioTek Instruments, Inc., Winooski, VT, USA). The suppression rate was calculated using the following formula: Suppression rate $=(1-\mathrm{A} / \mathrm{C}) \times 100 \%$, where $\mathrm{A}$ and $\mathrm{C}$ represent the number of cells treated with or without isatin, respectively. The MTT assay was performed six times.

Monolayer wound healing assay. Cells were seeded into individual wells of a six-well culture plate and grown to confluence. In order to suppress the contribution of cell proliferation, cells were grown in serum-free medium for $12 \mathrm{~h}$; furthermore, cells were treated with mitomycin $(10 \mu \mathrm{g} / \mathrm{ml}$; Bio Basic Canada, Inc., Markham, ON, Canada) for $3 \mathrm{~h}$ prior to wounding. A sterile $10-\mu 1$ pipette tip was then used to perform a longitudinal scratch in the confluent monolayer. The cell debris and medium were removed by aspiration and substituted with $2 \mathrm{ml}$ fresh serum-free medium. Images were captured at 0, 12, 24, 36 and $48 \mathrm{~h}$ after wounding (corresponding to 12, 24, 36, 48 and $60 \mathrm{~h}$ post-treatment) using an inverted microscope (CKX41; Olympus Corporation). Ten randomly selected points along each wound, which were used to mark the horizontal distance between the initial wound and the migrated cells, was measured. All images were processed using Image-Pro Plus 6.0 software (Media Cybernetics, Rockville, MD, USA).

Reverse-transcription quantitative polymerase chain reaction (RT-qPCR). Total RNA was extracted from SH-SY5Y cells cultured in the presence or absence of isatin using RNAiso Plus (Takara Biotechnology Co., Ltd., Dalian, China), according to the manufacturer's protocol. Total RNA was converted into cDNA using the Transcriptor First Strand cDNA Synthesis kit (Roche Diagnostics, Basel, Switzerland), under the following conditions: $50^{\circ} \mathrm{C}$ for $1 \mathrm{~h}$ followed by $85^{\circ} \mathrm{C}$ for $5 \mathrm{~min}$. cDNA was subjected to qPCR amplification in triplicate experiments using SYBR Green qPCR Master Mix (Takara Biotechnology Co., Ltd.) in a Real-Time PCR System (LightCycler ${ }^{\circledR}$ 96; Roche Diagnostics). The qPCR amplification conditions were as follows: $95^{\circ} \mathrm{C}$ for $30 \mathrm{sec}$, followed by 45 cycles of $95^{\circ} \mathrm{C}$ for $5 \mathrm{sec}, 60^{\circ} \mathrm{C}$ for $20 \mathrm{sec}$ and $72^{\circ} \mathrm{C}$ for $30 \mathrm{sec}$. Quantification relative to GAPDH was performed using the $2^{-\Delta \Delta \mathrm{Cq}}$ method (14). Real-time PCR was performed using the following primers (Shanghai Sunny Biotech Co., Ltd., Shanghai, China): GAPDH forward, 5'-AACAGCCTCAAGATCATCAGCAA-3' and reverse, 5'-GACTGTGGTCATGAGTCCTTCCA-3'; MMP2 forward, 5'-TTCCCTCGCAAGCCCAAGTG-3' and reverse, 5'-CTCCCAGCGGCCAAAGTTGA-3'; MMP9 forward, 5'-GCTGACTCGACGGTGATGGG-3' and reverse, 5'-GCC CCACTTCTTGTCGCTGT-3'.

Protein extraction and western blot analysis. SH-SY5Y cells were harvested and treated with isatin for $48 \mathrm{~h}$. The cells were lysed in radioimmunoprecipitation assay buffer (Solarbio Science \& Technology Co., Ltd.) for $20 \mathrm{~min}$ on ice. The homogenate was centrifuged for $5 \mathrm{~min}$ at 13,200 $\mathrm{xg}$ and the protein concentration in the supernatant was quantified using the bicinchoninic acid protein assay (Beyotime Institute of Biotechnology, Inc., Shanghai, China). Following storage at $-80^{\circ} \mathrm{C}, 30 \mu \mathrm{g}$ protein from each sample was separated by $0.1 \%$ sodium dodecyl sulfate-polyacrylamide gel electrophoresis (Sigma-Aldrich) and electrotransferred onto polyvinylidene difluoride membranes (Millipore, Billerica, MA, USA). The membranes were individually blocked with 5\% 
A

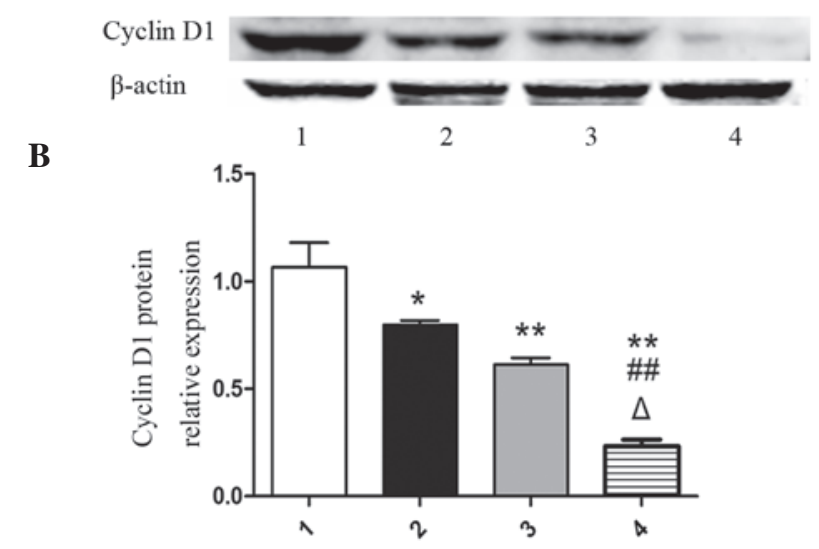

Figure 1. Isatin impedes the expression of cyclin D1. (A) Expression of cyclin D1 in SH-SY5Y cells after $48 \mathrm{~h}$ of treatment with isatin as detected by western blot analysis. Lanes: 1, control cells; 2-4, SH-SY5Y cells treated with 100, 200 and $400 \mu \mathrm{M}$ isatin, respectively. (B) Statistical analysis of the expression of cyclin D1 protein. Values are expressed as the mean \pm standard deviation. ${ }^{*} \mathrm{P}<0.05$ compared with control; ${ }^{* *} \mathrm{P}<0.01$ compared with control; ${ }^{\# \#} \mathrm{P}<0.01$ compared with $100 \mu \mathrm{M}$ isatin; ${ }^{\Delta} \mathrm{P}<0.05$ compared with $200 \mu \mathrm{M}$ isatin.

bovine serum albumin (Amresco, LLC, Solon, OH, USA) and then incubated with mouse anti- $\beta$-actin monoclonal antibody (1:1,000; TA-09; Zhongshan Golden Bridge Biotechnology, Beijing, China), rabbit anti-cyclin D1 monoclonal antibody (1:1,000; 2978; Cell Signaling Technology, Inc., Danvers, MA, USA), rabbit anti-matrix metalloproteinase (MMP)2 polyclonal antibody (1:1,000; 4022; Cell Signaling Technology), rabbit anti-MMP9 monoclonal antibody $(1: 3,000$; ab76003; Abcam, Cambridge, UK) and rabbit anti-phosphorylated signal transducer and activator of transcription 3 (pSTAT3) monoclonal antibody $(1: 2,000$; Tyr705; Cell Signaling Technology) for $2 \mathrm{~h}$ at room temperature, followed by further incubation at $4^{\circ} \mathrm{C}$ overnight. The blots were washed three times for $10 \mathrm{~min}$ each in Tris-buffered saline (Sangon Biotech Co., Ltd., Shanghai, China) containing $0.1 \%$ Tween 20 (TBST; Bio Basic Canada, Inc.) and then incubated with secondary horseradish peroxidase-conjugated goat anti-rabbit (1:2,000; BA1054; Boster Biological Technology, Ltd., Wuhan, China) and goat anti-mouse (1:5,000; ZB-2305; Zhongshan Golden Bridge Biotechnology) monoclonal antibodies for $1 \mathrm{~h}$ at room temperature. Following three washes in TBST for $10 \mathrm{~min}$ each, proteins were detected using an Enhanced Chemiluminescence Plus kit (Cyanagen, Bologna, Italy) by a chemiluminescence system (Fusion FX7; Vilber Lourmat, Collégien, France). Densitometric analysis was performed with Quantity One software, version 4.6.2 (Bio-Rad Laboratories, Inc., Hercules, CA, USA).

Statistical analysis. Each experiment was performed at least three times. Values are expressed as the mean \pm standard deviation. Statistical analysis included one-way analysis of variance, which was performed using SPSS software, version 20.0 (IBM SPSS, Armonk, NY, USA). When the differences between average levels among several groups were statistically significant, the Bonferroni multiple-comparisons test was performed. $\mathrm{P}<0.05$ was considered to indicate as statistically significant difference.
A

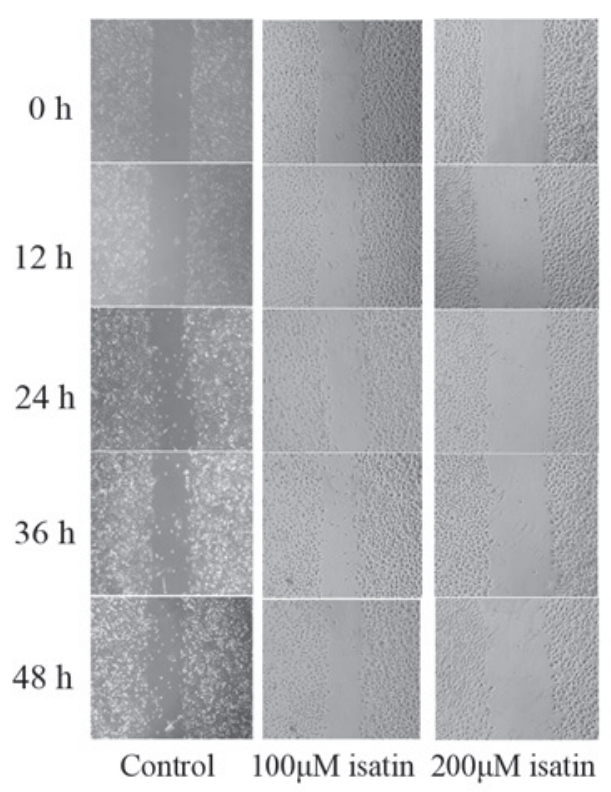

B

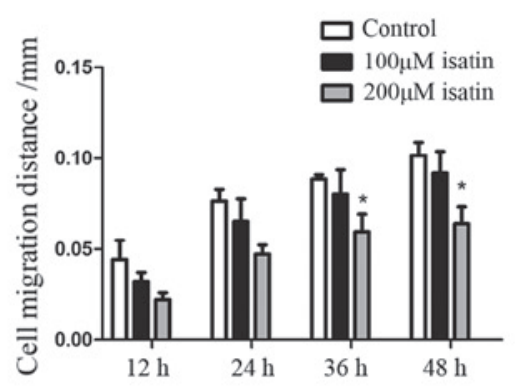

C

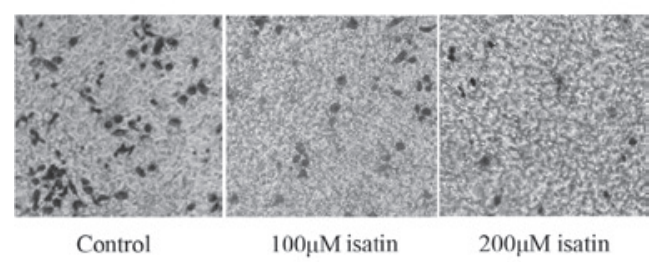

D

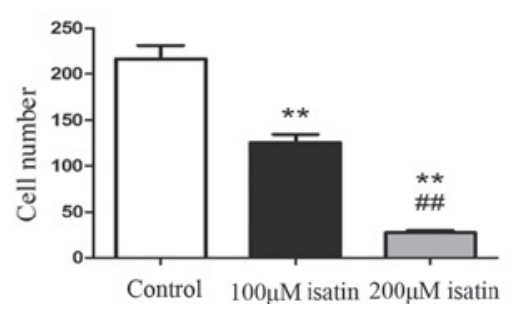

Figure 2. Isatin inhibits SH-SY5Y cell migration and invasion. (A) Effects of isatin on cell migration were examined using a wound closure assay (magnification, x100). Cells were treated with isatin and observed by microscopy at the indicated times. (B) Cell migration distance was determined by quantification of the results of the wound healing assay. (C) The invasive capacity was determined using a Transwell assay (magnification, x200). (D) Statistical analysis of the number of invaded cells in the Transwell assay. Values are expressed as the mean \pm standard deviation. ${ }^{*} \mathrm{P}<0.05,{ }^{* *} \mathrm{P}<0.01$ compared with control; ${ }^{\# \#} \mathrm{P}<0.01$ compared with $100 \mu \mathrm{M}$ isatin.

\section{Results}

Isatin enhances the $G_{I}$-phase population of SH-SY5Y cells. Following administration of isatin for $48 \mathrm{~h}$, cell cycle analysis was performed by flow cytometry. The results revealed that isatin significantly increased the proportion of cells in $\mathrm{G}_{1}$ phase 

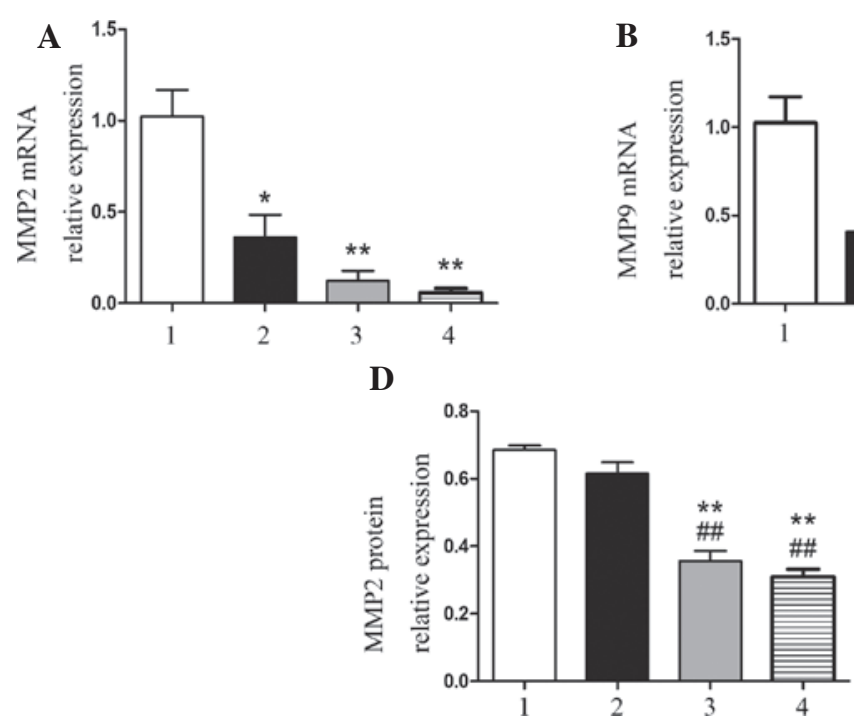

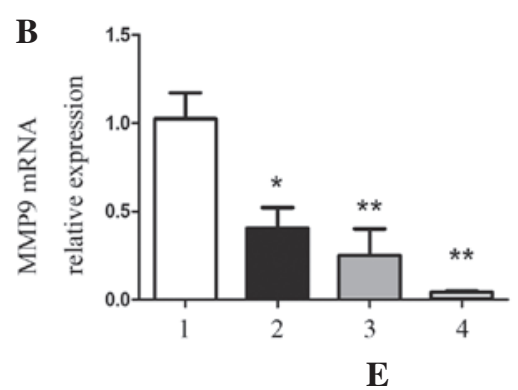

C
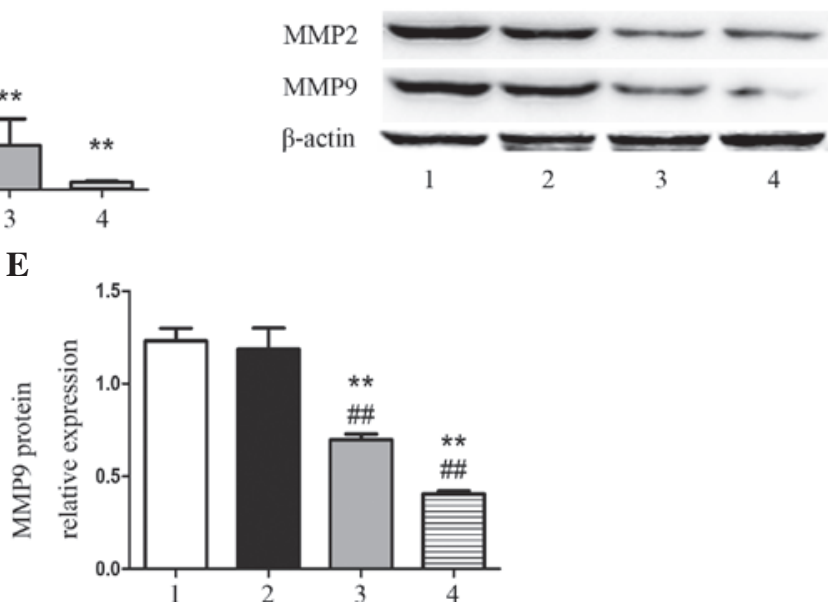

Figure 3. Isatin treatment decreased the protein and mRNA expression of MMPs in SHSY-5Y cells. Relative mRNA expression of (A) MMP2 and (B) MMP9 normalized to GAPDH. (C) Representative western blot of MMP2 and MMP9 protein in SH-SY5Y cells incubated with isatin for 48 h. Expression of (D) MMP2 and (E) MMP9 protein was quantified by densitometric analysis. $\beta$-actin was used as a loading control. Lanes/groups: 1, control cells; 2 -4: SH-SY5Y cells treated with 100,200 or $400 \mu \mathrm{mol} / 1$ isatin, respectively. Values are expressed as the mean \pm standard deviation. ${ }^{*} \mathrm{P}<0.05,{ }^{* *} \mathrm{P}<0.01 \mathrm{compared}$ with control; ${ }^{\# \#} \mathrm{P}<0.01$ compared with $100 \mu \mathrm{M}$ isatin. MMP, matrix metalloproteinase.

Table II. Inhibitory effect of isatin on human SHSY-5Y cells, as measured by an MTT assay.

\begin{tabular}{lcc}
\hline Group & $\mathrm{OD}_{490}$ & Suppression rate $(\%)$ \\
\hline Control & $0.2401 \pm 0.0280$ & -- \\
Isatin & & \\
$100 \mu \mathrm{M}$ & $0.1976 \pm 0.0218^{\mathrm{a}}$ & $14.8 \pm 1.7^{\mathrm{a}}$ \\
$200 \mu \mathrm{M}$ & $0.1832 \pm 0.0301^{\mathrm{a}}$ & $18.5 \pm 3.1^{\mathrm{a}}$ \\
$400 \mu \mathrm{M}$ & $0.1796 \pm 0.0201^{\mathrm{a}, \mathrm{b}}$ & $22.1 \pm 2.4^{\mathrm{a}, \mathrm{b}}$ \\
\hline
\end{tabular}

Values are expressed as the mean \pm standard deviation. ${ }^{\mathrm{a}} \mathrm{P}<0.05$ vs. the control group; ${ }^{\mathrm{b}} \mathrm{P}<0.05 \mathrm{vs}$. the $100 \mu \mathrm{M}$ isatin group.

$(\mathrm{P}<0.01)$ and significantly decreased the proportion of cells in $S$ phase $(P<0.01)$, while the proportion of cells in the $G_{2} / M$ phase was not altered (Table I). Compared with the 100 and $200 \mu \mathrm{M}$ groups, treatment with $400 \mu \mathrm{M}$ isatin resulted in a significantly higher increase in $\mathrm{G}_{1}$-phase and decrease in S-phase populations $(\mathrm{P}<0.01)$. These results suggested that isatin significantly caused $\mathrm{G}_{1}$-phase arrest in SH-SY5Y cells.

Isatin impedes the expression of cyclin D1. As cyclin D1 activation regulates the transcription of genes associated with cell proliferation (15), the present study investigated the impact of isatin on the expression of cyclin D1. As shown in Fig. 1, isatin significantly reduced the protein expression of cyclin D1 compared with that in the control group $(\mathrm{P}<0.01)$. Furthermore, cyclin D1 expresion in the $400 \mu \mathrm{M}$ isatin group was significantly decreased compared with that in the 100 and $200 \mu \mathrm{M}$ groups $(\mathrm{P}<0.01)$.

Isatin inhibits the invasive and migratory capacity of SH-SY5Y cells. The impact of isatin on the invasion and migration of
$\mathbf{A}$

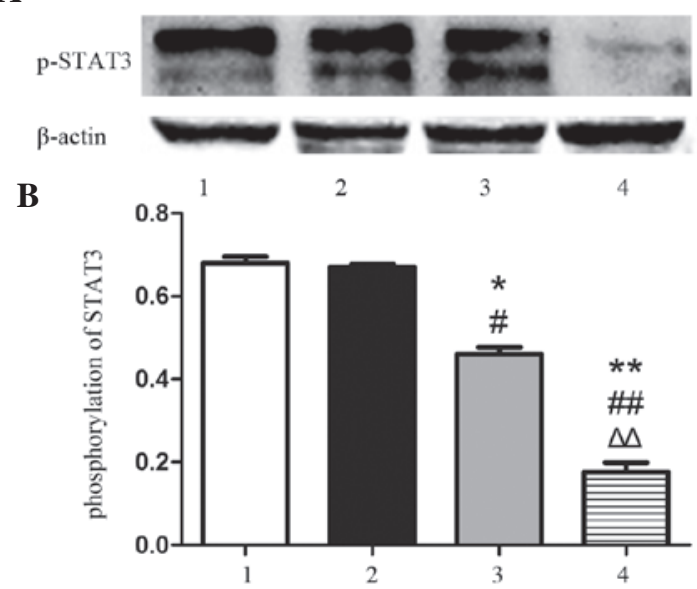

Figure 4. Isatin restrains the phosphorylation of STAT3. (A) Representative western blot of the expression of pSTAT3 in SH-SY5Y cells after $48 \mathrm{~h}$ of treatment with isatin. (B) Levels of phosphorylated STAT3 were determined by densitometric analysis with normalization to $\beta$-actin. Values are expressed as the mean \pm standard deviation. ${ }^{*} \mathrm{P}<0.05,{ }^{* *} \mathrm{P}<0.01$ compared with control; ${ }^{\#} \mathrm{P}<0.05,{ }^{\# \#} \mathrm{P}<0.01$ compared with $100 \mu \mathrm{M}$ isatin; ${ }^{\Delta \Delta} \mathrm{P}<0.01$ compared with $200 \mu \mathrm{M}$ isatin. Lanes/groups: 1, control cells; 2-4, SH-SY5Y cells treated with 100, 200 and $400 \mu \mathrm{mol} / \mathrm{l}$ isatin, respectively. pSTAT3, phosphorylated signal transducer and enhancer of transcription 3.

neuroblastoma cells was assessed using in vitro Transwell and wound-healing assays. As illustrated in Fig. 2A and B, $200 \mu \mathrm{M}$ isatin significantly restrained the invasiveness of $\mathrm{SH}-\mathrm{SY} 5 \mathrm{Y}$ cells $(\mathrm{P}<0.01)$. Furthermore $200 \mu \mathrm{M}$ isatin reduced the migratory ability of these cells after $36 \mathrm{~h}(\mathrm{P}=0.046)$ and $48 \mathrm{~h}$ of incubation ( $\mathrm{P}=0.035)$ (Fig. $2 \mathrm{C}$ and $\mathrm{D}$ ). These results suggested that isatin reduces the invasion and migration of the SH-SY5Y human neuroblastoma cell line.

Isatin inhibits the proliferation of SH-SY5Y cells. The effect of isatin on the proliferation of SH-SY5Y cells was investi- 
gated using an MTT assay. As is shown in Table II, isatin significantly inhibited the proliferation of SH-SY5Y cells $(\mathrm{P}<0.01)$, as compared with the control. In addition, the $\mathrm{OD}_{490}$ and suppression rate of SH-SY5Y cells were significantly decreased $(\mathrm{P}<0.05)$. Notably, the $400 \mu \mathrm{M}$ isatin group resulted in a more significant decrease, as compared with the $100 \mu \mathrm{M}$ group $(\mathrm{P}<0.05)$.

Isatin reduces the expression of $M M P 2$ and $M M P 9$. As it is known that MMP-2 and MMP-9 expression is relevant to metastasis and progression of neuroblastoma (16), the present study assessed the impact of isatin on MMP2 and MMP9 mRNA and protein expression in SH-SY5Y cells. As shown in Fig. 3A and $\mathrm{B}, 100 \mu \mathrm{M}$ isatin significantly reduced the mRNA expression of MMP2 $(\mathrm{P}=0.010)$ and MMP9 $(\mathrm{P}=0.040)$; however, at this concentration, isatin did not significantly affect the protein expression of these MMPs $(\mathrm{P}=0.520$ and $\mathrm{P}=0.661)$ (Fig. 3C-E). Of note, at 200 and $400 \mu \mathrm{M}$, isatin significantly inhibited the mRNA and protein expression of MMP2 and MMP9 compared with that in the control $(\mathrm{P}<0.01)$.

Isatin restrains the phosphorylation of STAT3. As pSTAT3 has been suggested to be the active form of STAT3 (17), the present study determined the protein levels of pSTAT3 (Tyr705) by western blot analysis. As shown in Fig. 4, the phosphorylation of STAT3 in the $100-\mu \mathrm{M}$ group was not markedly affected, while $200 \mu \mathrm{M}$ isatin significantly inhibited the phosphorylation of STAT3 $(\mathrm{P}<0.05)$, and $400 \mu \mathrm{M}$ isatin further diminished the activation of STAT3 $(\mathrm{P}<0.01)$.

\section{Discussion}

The results of the present study showed that isatin caused cell-cycle arrest of SH-SY5Y cells in $\mathrm{G}_{0} / \mathrm{G}_{1}$ phase. It is well established that cyclins regulate various phases of the cell cycle $(18,19)$. Cyclin D1 is one of the key regulatory proteins for the $G_{1}-S$ transition of the cell cycle. Overexpression of cyclin D1 has been found in numerous types of solid tumor, including neuroblastoma, bladder cancer, prostate cancer and breast cancer (20-23). The results of the present study suggested that isatin causes $\mathrm{G}_{1}$-phase arrest and inhibits the proliferation of SH-SY5Y cells by downregulating cyclin D1 expression.

The majority of neuroblastoma-associated mortalities occur due to metastasis to lymph nodes and bones $(24,25)$. Therefore, inhibiting cancer-cell migration and invasion is crucial in limiting metastasis (26). Neuroblastoma-cell invasiveness and metastasis are dependent on the ability of tumor cells to degrade the extracellular matrix (ECM) to detach from the primary tumor and enter the bloodstream or lymphatic system, followed by re-attachment at distant sites (27). MMPs are an important class of ECM-degrading enzymes, with gelatinases MMP2 and MMP9 known to be correlated with metastatic, aggressive or invasive tumor phenotypes (28-30). Therefore, the inhibition of MMP2 and MMP9 may be a useful strategy to inhibit metastasis formation and cancer progression in early tumor stages. The results of the present study showed that isatin inhibited the mRNA and protein expression of MMP2 and MMP9, which implied that isatin distinctly impedes the migration and invasion of neuroblastoma cells by decreasing MMP2 and MMP9.
STAT3 has a major role in tumor formation, as it is the point of convergence of multiple signaling pathways triggered by growth factors, cytokines and oncogenes. Considerable evidence has implicated STAT3 in the regulation of cellular apoptosis, tumor proliferation, invasion/metastasis and angiogenesis (31-33). Target genes of STAT3 include several members of the MMP family, D-type cyclins, vascular endothelial growth factor (VEGF) and B-cell lymphoma 2 (Bcl-2)/Bcl-2-associated X protein (Bax) (34-37). The results of the present study showed that isatin inhibited the expression of MMP family and D-type cyclins. Previous studies by our group indicated that isatin regulates $\mathrm{Bcl}-2 / \mathrm{Bax}$ and VEGF expression $(12,13)$. Hence, isatin may downregulate these genes by restraining the phosphorylation of STAT3.

The present study confirmed that isatin is an effective inhibitor of neuroblastoma-cell proliferation and metastasis. It inhibits the proliferation of SH-SY5Y cells by reducing the expression of cyclin D1 and impedes cell migration and invasion by decreasing MMP2 and MMP9. The observed effects of isatin on tumor-cell migration and proliferation are likely to be associated with pSTAT3. Isatin is a promising candidate for the clinical treatment of human neuroblastoma, which should be evaluated in in vivo studies.

\section{Acknowledgements}

The present study was supported by the National Natural Science Foundation of China (grant no. 81472542).

\section{References}

1. Beierle EA, Ma X, Stewart J, Nyberg C, Trujillo A, Cance WG and Golubovskaya VM: Inhibition of focal adhesion kinase decreases tumor growth in human neuroblastoma. Cell Cycle 9: 1005-1015, 2010.

2. Rössler J, Monnet Y, Farace F, Opolon P, Daudigeos-Dubus E, Bourredjem A, Vassal G and Geoerger B: The selective VEGFR1-3 inhibitor axitinib (AG-013736) shows antitumor activity in human neuroblastoma xenografts. Int J Cancer 128: 2748-2758, 2011.

3. Lee S, Qiao J, Paul P and Chung DH: Integrin $\beta 1$ is critical for gastrin-releasing peptide receptor-mediated neuroblastoma cell migration and invasion. Surgery 154: 369-375, 2013.

4. Siegel R, Naishadham D and Jemal A: Cancer statistics, 2013. CA Cancer J Clin 63: 11-30, 2013

5. Hayashi M, Okabe K, Kato K, Okumura M, Fukui R, Fukushima $\mathrm{N}$ and Tsujiuchi T: Differential function of lysophosphatidic acid receptors in cell proliferation and migration of neuroblastoma cells. Cancer Lett 316: 91-96, 2012.

6. Gencer N, Sonmez F, Demir D, Arslan O and Kucukislamoglu M: Synthesis, structure-activity relationships and biological activity of new isatin derivatives as tyrosinase inhibitors. Curr Top Med Chem 14: 1450-1462, 2014.

7. Bürger S, Yafai Y, Bigl M, Wiedemann P and Schliebs R: Effect of VEGF and its receptor antagonist SU-5416, an inhibitor of angiogenesis, on processing of the $\beta$-amyloid precursor protein in primary neuronal cells derived from brain tissue of $\mathrm{Tg} 2576$ mice. Int J Dev Neurosci 28: 597-604, 2010.

8. Lane ME, Yu B, Rice A, Lipson KE, Liang C, Sun L, Tang C, McMahon G, Pestell RG and Wadler S: A novel cdk2-selective inhibitor, SU9516, induces apoptosis in colon carcinoma cells. Cancer Res 61: 6170-6177, 2001.

9. Uchiyama H, Sowa Y, Wakada M, Yogosawa M, Nakanishi R, Horinaka M, Shimazaki C, Taniwaki M and Sakai T: Cyclin-dependent kinase inhibitor SU9516 enhances sensitivity to methotrexate in human T-cell leukemia Jurkat cells. Cancer Sci 101: 728-734, 2010.

10. Moshinsky DJ, Bellamacina CR, Boisvert DC, Huang P, Hui T, Jancarik J, Kim SH and Rice AG: SU9516: Biochemical analysis of cdk inhibition and crystal structure in complex with cdk2. Biochem Biophys Res Commun 310: 1026-1031, 2003. 
11. Mohammadi M, McMahon G, Sun L, Tang C, Hirth P, Yeh BK, Hubbard SR and Schlessinger J: Structures of the tyrosine kinase domain of fibroblast growth factor receptor in complex with inhibitors. Science 276: 955-960, 1997.

12. Hou L, Ju C, Zhang J, Song J, Ge Y and Yue W: Antitumor effects of Isatin on human neuroblastoma cell line (SH-SY5Y) and the related mechanism. Eur J Pharmacol 589: 27-31, 2008.

13. Song J, Hou L, Ju C, Zhang J, Ge Y and Yue W: Isatin inhibits proliferation and induces apoptosis of SH-SY5Y neuroblastoma cells in vitro and in vivo. Eur J Pharmacol 702: 235-241, 2013.

14. Livak KJ and Schmittgen TD: Analysis of Relative Gene Expression Data Using Real-Time Quantitative PCR and the 2$\Delta \Delta C T$ Method. Methods 25: 402-408, 2001.

15. Baldin V, Lukas J, Marcote MJ, Pagano M and Draetta G: Cyclin D1 is a nuclear protein required for cell cycle progression in G1. Genes Dev 7: 812-821, 1993.

16. Lu HF, Lai KC, Hsu SC, Lin HJ, Kuo CL, Liao CL, Yang JS and Chung JG: Involvement of matrix metalloproteinases on the inhibition of cells invasion and migration by emodin in human neuroblastoma SH-SY5Y cells. Neurochem Res 34: 1575-1583, 2009.

17. Hodge DR, Hurt EM and Farrar WL: The role of IL-6 and STAT3 in inflammation and cancer. Eur J Cancer 41: 2502-2512, 2005.

18. Molinari M: Cell cycle checkpoints and their inactivation in human cancer. Cell Prolif 33: 261-274, 2000.

19. Sankpal UT, Abdelrahim M, Connelly SF, Lee CM, Madero-Visbal R, Colon J, Smith J, Safe S, Maliakal P and Basha R: Small molecule tolfenamic acid inhibits PC-3 cell proliferation and invasion in vitro and tumor grow th in orthotopic mouse model for prostate cancer. Prostate 72: 1648-1658, 2012.

20. Comstock CE, Revelo MP, Buncher CR and Knudsen KE: Impact of differential cyclin D1 expression and localisation in prostate cancer. Br J Cancer 96: 970-979, 2007.

21. Zhu S, Mott RT, Fry EA, Taneja P, Kulik G, Sui G and Inoue K Cooperation between Dmp1 loss and cyclin D1 overexpression in breast cancer. Am J Pathol 183: 1339-1350, 2013.

22. Zaravinos A, Lambrou GI, Volanis D, Delakas D and Spandidos DA: Spotlight on differentially expressed genes in urinary bladder cancer. PLoS One 6: e18255, 2011.

23. Tsioras K, Papastefanaki F, Politis PK, Matsas R and Gaitanou M: Functional Interactions between BM88/Cend1, Ran-binding protein $\mathrm{M}$ and Dyrk1B kinase affect cyclin D1 levels and cell cycle progression/exit in mouse neuroblastoma cells. PLoS One 8: e82172, 2013.

24. Matthay KK, Villablanca JG, Seeger RC, Stram DO, Harris RE, Ramsay NK, Swift P, Shimada H, Black CT, Brodeur GM, et al: Treatment of high-risk neuroblastoma with intensive chemotherapy, radiotherapy, autologous bone marrow transplantation and 13-cis-retinoic acid. Children's cancer group. N Engl J Med 341: 1165-1173, 1999.
25. Monclair T, Brodeur GM, Ambros PF, Brisse HJ, Cecchetto G, Holmes K, Kaneko M, London WB, Matthay KK, Nuchtern JG, et al: The International neuroblastoma risk group (INRG) staging system: An INRG task force report. J Clin Oncol 27: 298-303, 2009.

26. Steeg PS and Theodorescu D: Metastasis: A therapeutic target for cancer. Nat Clin Pract Oncol 5: 206-219, 2008.

27. Paz H, Pathak $\mathrm{N}$ and Yang J: Invading one step at a time: The role of invadopodia in tumor metastasis. Oncogene 33: 4193-4202, 2014.

28. Hua H, Li M, Luo T, Yin Y and Jiang Y: Matrix metalloproteinases in tumorigenesis: An evolving paradigm. Cell Mol Life Sci 68: 3853-3868, 2011.

29. Chaudhary AK, Singh M, Bharti AC, Asotra K, Sundaram S and Mehrotra R: Genetic polymorphisms of matrix metalloproteinases and their inhibitors in potentially malignant and malignant lesions of the head and neck. J Biomed Sci 17: 10, 2010.

30. DeClerck YA, Perez N, Shimada H, Boone TC, Langley KE and Taylor SM: Inhibition of invasion and metastasis in cells transfected with an inhibitor of metalloproteinases. Cancer Res 52: 701-708, 1992.

31. Liu H, Jiang C, Xiong C and Ruan J: DEDC, a new flavonoid induces apoptosis via a ROS-dependent mechanism in human neuroblastoma SH-SY5Y cells. Toxicol In Vitro 26: 16-23, 2012.

32. Kamran MZ, Patil P and Gude RP: Role of STAT3 in cancer metastasis and translational advances. Biomed Res Int 2013: 421821, 2013

33. Walker SR, Xiang M and Frank DA: Distinct roles of STAT3 and STAT5 in the pathogenesis and targeted therapy of breast cancer. Mol Cell Endocrinol 382: 616-621, 2014.

34. Overall CM and López-Otín C: Strategies for MMP inhibition in cancer: Innovations for the post-trial era. Nat Rev Cancer 2: 657-672, 2002.

35. Zhuang L, Lee CS, Scolyer RA, McCarthy SW, Zhang XD, Thompson JF and Hersey P: Mcl-1, Bcl-XL and Stat 3 expression are associated with progression of melanoma whereas Bcl-2, AP-2 and MITF levels decrease during progression of melanoma. Mod Pathol 20: 416-426, 2007.

36. Wang T, Niu G, Kortylewski M, Burdelya L, Shain K, Zhang S, Bhattacharya R, Gabrilovich D, Heller R, Coppola D, et al: Regulation of the innate and adaptive immune responses by Stat-3 signaling in tumor cells. Nat Med 10: 48-54, 2004.

37. Bollrath J, Phesse TJ, von Burstin VA, Putoczki T, Bennecke M, Bateman T, Nebelsiek T, Lundgren-May T, Canli O, Schwitalla S, et al: gp130-mediated Stat3 activation in enterocytes regulates cell survival and cell-cycle progression during colitis-associated tumorigenesis. Cancer Cell 15: 91-102, 2009. 